\title{
Isolation and characterization of hydrocarbon producing green alga Botryococcus braunii from Indian freshwater bodies
}

\author{
Chandrappa Dayananda \\ Plant Cell Biotechnology Department \\ Central Food Technological Research Institute \\ Mysore 570 020, India \\ Tel: 918212516501 \\ Fax: 918212517233 \\ E-mail: nanda.daya@gmail.com
}

\author{
Ravi Sarada* \\ Plant Cell Biotechnology Department \\ Central Food Technological Research Institute \\ Mysore 570 020, India \\ Tel: 918212516501 \\ Fax: 918212517233 \\ E-mail: sarada_ravi@yahoo.com \\ Vinod Kumar \\ Plant Cell Biotechnology Department \\ Central Food Technological Research Institute \\ Mysore 570 020, India \\ Tel: 918212516501 \\ Fax: 918212517233 \\ E-mail:pcbt@cscftri.ren.nic.in
}

\author{
Gokare Aswathanarayana Ravishankar \\ Plant Cell Biotechnology Department \\ Central Food Technological Research Institute \\ Mysore 570 020, India \\ Tel: 918212516501 \\ Fax: 918212517233 \\ E-mail: pcbt@cscftri.ren.nic.in
}

Financial support: Department of Biotechnology, Government of India, New Delhi, India.

Keywords: biomass, carbon dioxide, carotenoids, fatty acids, inter simple sequence repeats, saturated hydrocarbons.

\begin{abstract}
Abbreviations: FAME: fatty acid methyl esters
ISSR: inter simple sequence repeats

NOX: oxides of nitrogen

SEM: scanning electron microscopy

SOX: oxides of sulphur
\end{abstract}

Samples of green colonial unicellular microalga Botryococcus braunii were collected from Bear Shola Falls at Kodaikanal (latitude $10.31 \mathrm{~N}$ and longitude 77.32 E), Tamil Nadu, India. Specimens were isolated, cultured and examined for its hydrocarbon content, morphological features and DNA structural resemblance with the known strain to confirm its identity. Inter simple sequence repeats (ISSR) finger printing revealed strong genetic similarity among the authentic strain (B. braunii $\mathrm{N}-836$ ) and the Indian isolated strain (B. braunii CFTRI- Bb1) from
Kodaikanal. The type of hydrocarbons produced by the Kodaikanal isolates were analyzed and identified as saturated hydrocarbons in the range of $C_{21}$ to $C_{33}$ by GCMS. Tetracosane and octacosane were found as the major components among the saturated hydrocarbons produced by this alga, constituting $17.6 \%$ and $14.8 \%$ respectively. Hydrocarbon content of the organism was in the range of $13-18 \%$ of its dry biomass. The fat content of the organism was found to be $22 \%(w / w)$. Palmitic and oleic acids were found to be major fatty acids produced by the alga. Lutein and $\beta$-carotene were

*Corresponding author 
found to be the major carotenoids and constituted about $64.1 \%$ and $25.1 \%$ respectively of the total carotenoids. Based on ISSR finger printing and hydrocarbon analyses the new algal strain from Kodaikanal was identified as Botryococcus braunii.

The green colonial hydrocarbon rich unicellular microalgae Botryococcus braunii (Banerjee et al. 2002; Metzger and Largeau, 2005) is widespread in freshwater, brackish lakes, reservoirs and ponds. It is also widely distributed in reservoirs at temperate, tropical and arctic latitudes (Tyson, 1995). It is recognized as one of the potent renewable resource for production of liquid hydrocarbons. B. braunii is classified into $\mathrm{A}, \mathrm{B}$ and $\mathrm{L}$ races based on the type of hydrocarbons produced (Metzger and Largeau, 2005). Race - A produces $\mathrm{C}_{21}$ to $\mathrm{C}_{33}$ odd numbered $\mathrm{n}$-alkadienes, mono-, tri-, tetra-, and pentaenes and they are derived from fatty acids (Banerjee et al. 2002; Metzger et al. 2005). The L race yields a single $\mathrm{C}_{40}$ isoprenoid hydrocarbon, lycopa 14(E),18(E)-diene (Metzger et al. 1990). The B race produces two types of triterpenes called botryococcenes of $\mathrm{C}_{30}-\mathrm{C}_{37}$ of general formula $\mathrm{C}_{\mathrm{n}} \mathrm{H}_{2 \mathrm{n}-10}$ as major hydrocarbons and small amounts of methyl branched squalene. Certain strains of the B race also biosynthesise cyclobotryococcenes (David et al. 1988; Achitouv et al. 2004). Also a feature common to all three races is the presence of a highly aliphatic, non-hydrolysable and insoluble biomacromolecule (algaenan) found in their outer cell walls (Audino et al. 2002). The highly resistant nature of the $B$. braunii algaenan to degradation allows it to be selectively preserved during fossilisation, leading to fossil B. braunii remains, a major contributor to a number of high oil potential sediments (Simpson et al. 2003). The alga $B$. braunii produces hydrocarbon in the range of $2-86 \%$ (on dry weight basis). This variation in the content of hydrocarbon is due to the differences in the strains, the race it belongs and also depends on cultural and physiological conditions (Dayananda et al. 2005).

Hydrocarbon oils extracted from B. braunii, when hydrocracked, produce a distillate comprising of $67 \%$ gasoline fraction, $15 \%$ aviation turbine fuel, $15 \%$ diesel fuel fraction and 3\% residual oil (Banerjee et al. 2002; Dayananda et al. 2006), these fuels were free from oxides of sulphur and nitrogen (SOX and NOX) after their combustion. Being a photosynthetic organism, it can reduce $\mathrm{CO}_{2}$ emissions by $1.5 \times 10^{5}$ tons/yr and $8.4 \times 10^{3}$ ha of microalgal cultivation area would be necessary (Sawayama et al. 1999). The uptake of some toxic metals like chromium, cadmium and arsenic is also been reported (Sawayama et al. 1995). There is a need for isolation and identification of newer species or strains of Botryococcus which are efficient in hydrocarbon synthesis and could be adopted for the mass cultivation. In the present study focus was on isolation of indigenous strain of Botryococcus braunii from India and its characterization in hydrocarbons and carotenoids production. The effect of $\mathrm{pH}$ and carbon dioxide on its growth and hydrocarbon production was also studied and is reported here.

\section{MATERIALS AND METHODS}

\section{Algal strain}

An authentic strain of Botryococcus braunii (N-836) was obtained from the National Institute for Environmental Studies, Tsukuba, Japan. The stock culture was maintained on modified Chu 13 medium.

\section{Isolation and purification}

The samples were collected from different water bodies of Kodaikanal (latitude $10.31 \mathrm{~N}$ and longitude $77.32 \mathrm{E}$ ), (India) and cultured in modified Chu 13 medium (Largeau et al. 1980). The algae were subjected to purification by serial dilution followed by plating. The individual colonies were isolated and inoculated into liquid medium (modified Chu 13 medium) and incubated at $25 \pm 1^{\circ} \mathrm{C}$ under $1.2 \pm 0.2$ klux light intensity with 16:8 hrs light photoperiod. The purity of the culture was ensured by repeated plating and by regular observation under microscope.

A time course study was carried out on $B$. braunii growth. The experiment was carried out in Erlenmeyer flasks of 150 $\mathrm{ml}$ capacity, containing $40 \mathrm{ml}$ modified Chu 13 medium for a period of 3 weeks. The culture flasks were inoculated $(20 \% \mathrm{v} / \mathrm{v})$ and incubated at $25 \pm 1^{\circ} \mathrm{C}$ under $1.2 \pm 0.2 \mathrm{klux}$ light intensity with $16: 8 \mathrm{hrs}$ light and dark cycle. Cultures were harvested and dry biomass was estimated at 3 days of intervals. Cell free medium was also analyzed for residual phosphate, protein content. All the experiments were carried out in triplicates.

\section{Effect of pH}

The effect of $\mathrm{pH}$ on growth of the alga and hydrocarbon yields was studied using Chu 13 media in the $\mathrm{pH}$ range of $6.0,6.5,7.0,7.5,8.0$ and 8.5.The experiment was carried out in Erlenmeyer flasks $(150 \mathrm{ml})$ containing $40 \mathrm{ml}$ of Chu 13 modified medium and the $\mathrm{pH}$ of the medium was adjusted before autoclaving. All the flasks were inoculated uniformly at $25 \%(\mathrm{v} / \mathrm{v})$ inoculum of 2 weeks old $B$. braunii culture. The culture flasks were incubated for 3 weeks at 25 $\pm 1^{\circ} \mathrm{C}$ temperature with $1.2 \pm 0.2$ klux and $16: 8 \mathrm{hrs}$ light dark cycle, and the culture was harvested and analysed for biomass and hydrocarbon yields.

\section{Effect of carbon dioxide}

A two- tier Erlenmeyer flask (Tripathi et al. 2001) was used for photoautotrophic growth experiments. The medium in upper chamber was inoculated with $25 \%$ (v/v) of two week old $B$. braunii culture. The mouth of the upper and lower compartments was sealed tightly with cotton plug and parafilm. The mixture of carbonate $(3 \mathrm{M})$ and bicarbonate $(3 \mathrm{M})$ solutions were added $(100 \mathrm{~mL})$ to the lower compartments to get a $\mathrm{CO}_{2}$ partial pressure of $0.5,1.0$ and $2.0 \%(\mathrm{v} / \mathrm{v})$ respectively as given by Tripathi et al. (2001). The culture flasks were incubated for 3 weeks under 16:8 hrs light dark cycle with $1.2 \pm 0.2$ klux light intensity at 25 
$\pm 1^{\circ} \mathrm{C}$. The experiment was carried out in triplicates. The cultures were harvested and analysed for biomass and hydrocarbon yields.

\section{Biomass estimation}

The cultures were harvested and the cells were washed with distilled water after centrifugation at $5000 \mathrm{rpm}$. Then the pellet was freeze dried. The dry weight of algal biomass was determined gravimetrically and growth was expressed in terms of dry weight.

\section{Chlorophyll estimation}

A known volume of culture was centrifuged (8000 rpm) for 10 min and the pellet was treated with known volume of methanol and kept in water bath for $30 \mathrm{~min}$ at $60^{\circ} \mathrm{C}$. Absorbance of the pooled extracts was measured at 652 and $665 \mathrm{~nm}$ and chlorophyll $(\mathrm{a}+\mathrm{b})$ was estimated using Lichtenthaler equations (Lichtenthaler, 1987).

\section{Estimation of carotenoids}

A known quantity of algal dry biomass was homogenized and extracted repeatedly with acetone. The pooled extracts absorbance was read at $470 \mathrm{~nm}$ and total carotenoid contents were quantified according to Lichtenthaler (Lichtenthaler, 1987).

\section{Phosphate estimation}

The cells were harvested by centrifugation at $8000 \mathrm{rpm}$ and the supernatant was analyzed for phosphate content by Fiske-Subbarao's method (Fiske and Subbarow, 1925).

\section{Protein estimation}

Protein content in the cell free medium was analyzed by Bradford protein assay (Zor and Selinger, 1996)

\section{Hydrocarbon extraction}

Hydrocarbon was extracted in hexane after homogenizing the dry biomass in a mortar and pestle in the presence of glass powder and the supernatant recovered after centrifugation was evaporated to complete dryness under the stream of nitrogen. Hydrocarbon content was measured gravimetrically and expressed as dry weight percentage (Dayananda et al. 2005; Dayananda et al. 2006).

\section{Hydrocarbon analysis by GC-MS}

Hydrocarbon extract was purified by column chromatography on silica gel. The hydrocarbon samples were analyzed on SPB-1 column (30 m x $0.32 \mathrm{~mm}$ ID x $0.25 \mu \mathrm{m}$ film thickness) using GCMS equipped with FID and were identified by comparing their fragmentation pattern with standards (Sigma) and also with NIST library (Dayananda et al. 2005).

\section{Fatty acid analysis}

Lipids were extracted with chloroform - methanol (2:1) and quantified gravimetrically. The fatty acid methyl esters (FAME) were prepared as per the procedure of Christie (1982). FAME were analyzed by GC-MS (PerkinElmer, Turbomass Gold, Mass spectrometer) equipped with FID using SPB-1 (poly(dimethysiloxane)) capillary column (30 $\mathrm{m} \times 0.32 \mathrm{~mm}$ ID $\mathrm{x} 0.25 \mu \mathrm{m}$ film thickness) with a temperature programming $130^{\circ} \mathrm{C}$ to $280^{\circ} \mathrm{C}$ at a rate of $2^{\circ} \mathrm{C} / \mathrm{min}$. The FAME were identified by comparing their fragmentation pattern with authentic standards (Sigma) and also with NIST library (Dayananda et al. 2006).

\section{HPLC analysis of carotenoids}

The acetone extract of the alga B. braunii (CFTRI-1) was analysed by HPLC using a reversed phase C18 column (25 $\mathrm{cm} \times 4.6 \mathrm{~mm}$ ID) with an isocratic solvent system consisting of acetonitrile/methanol/dichloromethane $(7: 1: 2)$ at a flow rate of $1.0 \mathrm{ml} / \mathrm{min}$ and the compounds were detected at $450 \mathrm{~nm}$. Lutein, $\beta$-carotene were identified using authentic standards (Sigma).

\section{Scanning electron microscopy}

The cells were processed for scanning electron microscopy (SEM) according to Fowke et al. (1994). The samples were fixed in $2 \%$ glutaraldehyde in $0.2 \mathrm{M}$ phosphate buffer $(\mathrm{pH}$ 6.8) for $12 \mathrm{hrs}$, dried in alcohol series up to $100 \%$, sputter coated with gold and examined in a LEO Scanning Electron Microscope 435 VP (Leo Electron Microscopy Ltd., Cambridge, UK).

\section{ISSR fingerprinting of algal strains}

Genomic DNA was isolated using plant genomic DNA isolation kit (Sigma). Three inter simple sequence repeats (ISSR) primers $(\mathrm{AC})_{8} \mathrm{C},(\mathrm{GA})_{8} \mathrm{C},(\mathrm{GA})_{8} \mathrm{~T}$ were used for ISSR fingerprinting. The amplifications were carried out in 1X PCR buffer with $1.5 \mathrm{mM} \mathrm{MgCl} 2,2.5 \mathrm{mM}$ of dNTPs and 1 unit of Taq DNA polymerase (MBI fermentas, Lithuania), $200 \mathrm{nM}$ of each primer (Sigma). PCR was performed in a thermal cycler (Eppendorf Thermal Cycler) with a temperature programme involving initial denaturation at $94^{\circ} \mathrm{C}$ for $5 \mathrm{~min}$ followed by 35 cycles of $30 \mathrm{sec}$ denaturation at $94^{\circ} \mathrm{C}, 1 \mathrm{~min}$ at respective annealing temperature and 1 min extension at $72^{\circ} \mathrm{C}$ with a final extension of $72^{\circ} \mathrm{C}$ for $10 \mathrm{~min}$. The amplification products were separated by size on $1.2 \%$ agarose gels and stained with ethidium bromide observed under UV light and documented (Hero-Lab Gmbh. Germany). The PCR reactions were repeated at least twice to establish reproducibility.

\section{RESULTS AND DISCUSSION}

It has been reported that, Botryococcus braunii exists in the form of blooms in fresh water bodies like ponds, lakes and reservoirs (Metzger and Largeau, 2005). The samples 
collected in Bear Shola Falls (Kodaikanal, India) were initially cultured in modified Chu 13 medium and were purified by serial dilution fallowed by plating. The microscopic observations (Figure 1 and Figure 2) of the isolated alga revealed its colonial existence. Komárek and Marvan (1992) proposed the existence of at least 13 species of Botryococcus on the basis of morphological differences by omitting the chemical analyses. Metzger and Largeau (2005) reported that, within in each chemical race and for the same strain the morphology of the alga could vary in relation to age and culture conditions.

The morphological heterogeneity of the alga makes the identification difficult. So in the present study we used ISSR as a tool to identify the alga by comparing with the known strain and also the nature of hydrocarbons it synthesize. ISSR finger printing (Figure 3 ) revealed a very close genomic similarity among the known $B$. braunii $(B$. braunii N-836, National Institute for Environmental Studies, Tsukuba, Japan) and the isolated unknown alga. ISSR fingerprinting is a very potent tool to compare genomes for their identity. In some cases it is also possible to identify even minor somaclonal variations among the individuals (Rani et al. 2000; Li and Ge, 2001). However epigenetic variation related to change in DNA structure or methylation could not be explained by ISSR markers. ISSR markers have been successfully used in the determination of taxonomical relationships among species and subspecies (Hao et al. 2002; Vijayan et al. 2004). However, phylogenetic analyses of several strains of $B$. braunii were carried by 18 s rRNA sequence (Senousy et al. 2004). Based on the 18s rRNA sequence analysis they showed that, the four strains of $B$. braunii belong to three existing chemical races which form a monophyletic group.

The liquid culture developed from the single colonies was established in modified Chu 13 liquid medium and the cultures were maintained by sub culturing at two weeks intervals. The growth curve (Figure 4) shows that the alga grew exponentially up to two weeks followed by stationary phase. It is also evident from Figure 5, that the decrease in phosphate concentration in the medium indicates the utilization of phosphate for its active growth. After two weeks of growth, phosphate and protein in the spent medium increased and correlate with the stationary phase. The increase in both phosphate and protein concentrations in the spent medium may be due to lyses of the cells. Similar observations by Casadevall et al. (1985) demonstrated the utilization of phosphate in the early exponential growth of the alga and increased amount of phosphate in the final stages of the culture.

The early stationary phase culture was harvested, and the hydrocarbons were extracted from the dry biomass with hexane. Hydrocarbons were identified by their $\mathrm{M}^{+}$ions and comparison of the mass spectra with those of the standards (Sigma) and also with the NIST library. The types of hydrocarbons produced by the alga were identified as saturated hydrocarbons in the range of $\mathrm{C}_{21}$ to $\mathrm{C}_{33}$ (peak 1 to peak 13) by GCMS (Table 1; Figure 6 and Figure 7). Among the saturated hydrocarbons produced by the alga, tetracosane (peak 4) and octacosane (peak 8) were found to be the major and constituted $17.6 \%$ and $14.8 \%$ respectively, and their mass spectra and gas chromatograms have been presented in Figure 6 and Figure 7. Yang et al. (2004) reported that the alga B. braunii (obtained from Culture Collection of Algae, Institute of Hydrobiology, Chinese Academy of Sciences) produced saturated hydrocarbons in the range of $\mathrm{C}_{21}$ to $\mathrm{C}_{31}$ and heptacosane as the major constituent. It has been also reported that the $B$. braunii produced saturated straight-chain and branched-chain $\left(\mathrm{C}_{14^{-}}\right.$ $\left.\mathrm{C}_{28}\right)$ and long-chain linear aliphatic $\left(\mathrm{C}_{20}-\mathrm{C}_{27}\right)$ hydrocarbons in the range of $\mathrm{C}_{12}-\mathrm{C}_{32}$ (Banerjee et al. 2002; Volova et al. 2003). Thus the ISSR analysis and hydrocarbon profile of the algal isolate clearly indicates that the Indian isolate is Botryococcus braunii.

An increase of 1.1 to 1.3 fold in biomass yield was observed in B. braunii culture supplemented with carbon dioxide over the control (Figure 8). Similarly hydrocarbon accumulation also increased with the supplementation of carbon dioxide (Figure 8). Increase in chlorophyll and carotenoids contents was observed with increase in carbon dioxide supplementation up to $2 \%(\mathrm{v} / \mathrm{v})$ (Figure 9). This shows its effective utilization of carbon dioxide through photosynthesis. Tripathi et al. (2001) reported photoautotrophic growth of different microalgae for higher growth and carotenoid production. It was evident that different algae require different levels of $\mathrm{CO}_{2}$ for their photoautotrophic adaptability (Tripathi et al. 2001). In the present study $2 \%$ of $\mathrm{CO}_{2}$ supplementation was found to be better for growth and hydrocarbon production.

The fat content of the organism was found to be $22 \%(\mathrm{w} / \mathrm{w})$ while palmitic and oleic acids as the major fatty acids constituting 40.6 and $22.3 \%$ respectively (Table 2 ). Similar observations were made by Fang et al. (2004) and Dayananda et al. (2006) and they reported that palmitic acid and oleic acids as the major components in the B. braunii.

Lutein $(64.1 \%)$ and $\beta$-carotene $(25.1 \%)$ were found to be the major carotenoids (Figure 10) during the early stationary phase of the culture. In $\mathrm{CO}_{2}$ supplemented cultures, there was a 3.2 to 3.6 fold increase in $\beta$-carotene content (Figure 10) and total carotenoids content of the organism which enhanced (up to $1.75 \mathrm{mg} \mathrm{g}^{-1}$ ) with increasing carbon dioxide concentration (Figure 9).

From Figure 11 it is evident that there is no significant effect of $\mathrm{pH}$ on the biomass yield and production of hydrocarbons since they varied in the range of $0.75 \mathrm{gL}^{-1}$ to $0.86 \mathrm{gL}^{-1}$ and 13 to $15 \%(\mathrm{w} / \mathrm{w})$ respectively. However at $\mathrm{pH}$ 7.5 the algae showed maximum growth and production of hydrocarbons (Figure 11).

In conclusion, the alga B. braunii (CFTRI-Bb1) can be of use in production of hydrocarbons. The supplementation of $\mathrm{CO}_{2}$ enhanced both biomass and hydrocarbon production. 
The organism exhibited wide range of $\mathrm{pH}$ adaptability. With further understanding on the influence of cultural conditions on hydrocarbon production, the alga can be exploited for outdoor cultivation.

\section{ACKNOWLEDGMENTS}

We thank Dr. V. Prakash, Director, CFTRI for his encouragement in carrying out this study and Dr. Narasimha Rao, Regional Director, Indira Gandhi National Open University, Bangalore for his need full help and advice during sample collection.

\section{REFERENCES}

ACHITOUV, Etienne; METZGER, Pierre; RAGER, MarieNoëlle and LARGEAU, Claude. $\mathrm{C}_{31}-\mathrm{C}_{34}$ methylated squalene from a Bolivian strain of Botryococcus braunii. Phytochemistry, December 2004, vol. 65, no. 23, p. 31593165.

AUDINO, Michiele; GRICE, Kliti; ALEXANDER, Robert and KAGI, Robert I. Macrocyclic alkanes in crude oils from the algaenan of Botryococcus braunii. Organic Geochemistry, August 2002, vol. 33, no. 8, p. 979-984.

BANERJEE, A.; SHARMA, R.; CHISTY, Y. and BANERJEE, U.C. Botryococcus braunii: A renewable source of hydrocarbons and other chemicals. Critical Reviews in Biotechnology, September 2002, vol. 22, no. 3, p. 245-279.

CASADEVALL, E.; DIF, D.; LARGEAU, C.; GUDIN, C.; CHAUMONT, D. and DESANTI, O. Studies on batch and continuous cultures of Botryococcus braunii: hydrocarbon production in relation to physiological state, cell ultrastructure, and phosphate nutrition. Biotechnology and Bioengineering, March 1985, vol. 27, no. 3, p. 286-295.

CHRISTIE, William W. Lipid analysis, $2^{\text {nd }}$ ed. Pergamon press, New York, 1982. 338 p. ISBN 0-08-017753-0.

DAVID, M.; METZGER, P. and CASADEVALL, E. Two cyclobotryococcenes from the $\mathrm{B}$ race of the green alga Botryococcus braunii. Phytochemistry, 1988, vol. 27, no. 9, p. 2863-2867.

DAYANANDA, C.; SARADA, R.; BHATTACHARYA, S. and RAVISHANKAR, G.A. Effect of media and culture conditions on growth and hydrocarbon production by Botryococcus braunii. Process Biochemistry, September 2005, vol. 40, no. 9, p. 3125-3131.

DAYANANDA, C.; SARADA, R.; SRINIVAS, P.; SHAMALA, T.R. and RAVISHANKAR, G.A. Presence of methyl branched fatty acids and saturated hydrocarbons in botryococcene producing strain of Botryococcus braunii. Acta Physiologiae Plantarum, 2006, vol. 28, no. 3, p. 251256.
FANG, Jian-You; CHIU, Hsien-Chih; WU, Jiunn-Tzong; CHIANG, Yin-Ru and HSU, Shu-Hui. Fatty acids in Botryococcus braunii accelertate topical delivery of flurbiprofen into and across skin. International Journal of Pharmaceutics, May 2004, vol. 276, no. 1-2, p. 163-173.

FISKE, Cyrus H. and SUBBAROW, Yellapragada. The colorimetric determination of phosphorus. The Journal of Biological Chemistry, December 1925, vol. 66, no. 2, p. 375-400.

FOWKE, Larry C.; ATTREE, Stephen M. and RENNIE, Pat J. Scanning electron microscopy of hydrated and desiccated mature somatic embryos and zygotic embryos of white spruce (Picea glauca [Moench] Voss.). Plant Cell Reports, August 1994, vol. 13, no. 11, p. 612-618.

HAO, Gang; LEE, Dong-Hee; LEE, June Seung and LEE, Nam Sook. A study of taxonomical relationships among species of Korean Allium sect. Sacculiferum (Alliaceae) and related species using inter-simple sequence repeat (ISSR) markers. Botanical Bulletin of Academia Sinica, 2002, vol. 43, no. 1, p. 63-68.

KOMAREK, J. and MARVAN, P. Morphological differences in natural populations of the genus Botryococcus (chlorophyceae). Archiv für Protistenkunde, 1992, vol. 141, no. 1-2, p. 65-100.

LARGEAU, C.; CASADEVALL, E.; BERKALOFF, C. and DHAMELINCOURT, P. Sites of accumulation and composition of hydrocarbons in Botryococcus braunii. Phytochemistry, 1980, vol. 19, no. 6, p. 1043-1051.

LI, Ang and GE, Song. Genetic variation and clonal diversity of Psammochloa villosa (Poaceae) detected by ISSR markers. Annals of Botany, May 2001, vol. 87, no. 5, p. 585-590.

LICHTENTHALER, H.K. Chlorophylls and carotenoids: pigments of photosynthetic biomembranes. In: PACKER, L. and DOUCE, R. eds. Methods in Enzymology. Washington, Academic Press, 1987, vol. 148, p. 350-382.

METZGER, P. and LARGEAU, C. Botryococcus braunii: a rich source for hydrocarbons and related ether lipids. Applied Microbiology and Biotechnology, February 2005, vol. 66, no. 5, p. 486-496.

METZGER, Pierre; ALLARD, Béatrice; CASADEVALL, Eliette; BERKALOFF, Claire and COUTE, Alain. Structure and chemistry of a new chemical race of Botryococcus braunii (Chlorophyceae) that produces lycopadiene, a tetraterpenoid hydrocarbon. Journal of Phycology, June 1990, vol. 26, no. 2, p. 258-266.

RANI, V.; SINGH, K.P.; SHIRAN, B.; NANDY, S.; GOEL, S.; DEVARUMATH, R.M.; SREENATH, H.L. and RAINA, S.N. Evidence for new nuclear and mitochondrial genome organizations among high-frequency somatic 
embryogenesis-derived plants of allotetraploid Coffea arabica L. (Rubiaceae). Plant Cell Reports, October 2000, vol. 19, no. 10, p. 1013-1020.

SAWAYAMA, Shigeki; INOUE, Seiichi; DOTE, Yutaka and YOKOYAMA, Shin-Ya. $\mathrm{CO}_{2}$ fixation and oil production through microalga. Energy Conversion and Management, June-September 1995, vol. 36, no. 6-9, p. 729-731.

SAWAYAMA, Shigeki; MINOWA, T. and YOKOYAMA, Shin-Ya. Possibility of renewable energy production and carbon dioxide $\left(\mathrm{CO}_{2}\right)$ mitigation by thermochemical liquefaction of microalgae. Biomass and Bioenergy, July 1999, vol. 17, no. 1, p. 33-39.

SENOUSY, Hoda H.; BEAKES, Gordon W. and HACK, Ethan. Phylogenetic placement of Botryococcus braunii (Trebouxiophyceae) and Botryococcus sudeticus isolate UTEX 2629 (Chlorophyceae). Journal of Phycology, April 2004, vol. 40, no. 2, p. 412-423.

SIMPSON, Andre J.; ZANG, Xu; KRAMER, Robert and HATCHER, Patrick G. New insights on the structure of algaenan from Botryococcus braunii race A and its hexane insoluble botryals based on multidimensional NMR spectroscopy and electrospray-mass spectrometry techniques. Phytochemistry, March 2003, vol. 62, no. 5, p. 783-796.

TRIPATHI, U.; SARADA, R. and RAVISHANKAR, G.A. A culture method for microalgal forms using two-tier vessel providing carbon-dioxide environment: studies on growth and carotenoids production. World Journal of Microbiology and Biotechnology, June 2001, vol. 17, no. 4, p. 325-329.

TYSON, R.V. Sedimentary organic matter: Organic facies and palynofacies. Chapman and Hall, New York, 1995. 400 p. ISBN 0-41-236350-X.

VIJAYAN, K.; SRIVASTAVA, P.P. and AWASTHI, A.K. Analysis of phylogenetic relationship among five mulberry (Morus) species using molecular markers. Genome, June 2004, vol. 47, no. 3, p. 439-448.

VOLOVA, T.G.; KALACHEVA, G.S. and ZHILA, N.O. Specificity of lipid composition in two Botryococcus strains, the producers of liquid hydrocarbons. Russian Journal of Plant Physiology, September 2003, vol. 50, no. 5, p. 627-633.

YANG, Suling; WANG, Jun; CONG, Wei; CAI, Zhaoling and OUYANG, Fan. Effects of bisulfite and sulfite on the microalga Botryococcus braunii. Enzyme and Microbial Technology, July 2004, vol. 35, no. 1, p. 46-50.

ZOR, Tsaffrir and SELINGER, Zvi. Linearization of the Bradford protein assay increases its sensitivity: theoretical and experimental studies. Analytical Biochemistry, May 1996, vol. 236, no. 2, p. 302-308. 


\section{APPENDIX}

\section{TABLES}

Table 1. Hydrocarbons produced by the alga Botryococcus braunii (CFTRI-Bb1).

\begin{tabular}{|c|c|c|}
\hline Peak no. & Compound & Relative \% \\
\hline 1 & $\mathrm{C}_{21}$ & $05.01 \pm 0.21$ \\
\hline 2 & $\mathrm{C}_{22}$ & $12.43 \pm 1.23$ \\
\hline 3 & $\mathrm{C}_{23}$ & $08.79 \pm 0.60$ \\
\hline 4 & $\mathrm{C}_{24}$ & $17.76 \pm 2.07$ \\
\hline 5 & $\mathrm{C}_{25}$ & $12.28 \pm 0.98$ \\
\hline 6 & $\mathrm{C}_{26}$ & $10.96 \pm 0.34$ \\
\hline 7 & $\mathrm{C}_{27}$ & $09.56 \pm 0.27$ \\
\hline 8 & $\mathrm{C}_{28}$ & $14.83 \pm 0.67$ \\
\hline 9 & $\mathrm{C}_{29}$ & $03.50 \pm 0.97$ \\
\hline 10 & $\mathrm{C}_{30}$ & $02.05 \pm 0.48$ \\
\hline 11 & $\mathrm{C}_{31}$ & $01.46 \pm 0.59$ \\
\hline 12 & $\mathrm{C}_{32}$ & $00.74 \pm 0.35$ \\
\hline 13 & $\mathrm{C}_{33}$ & $00.54 \pm 0.10$ \\
\hline & & \\
\hline
\end{tabular}

Table 2. Lipid profile of Botryococcus braunii (CFTRI- Bb1).

\begin{tabular}{|c|c|}
\hline Fatty acids & Relative \% \\
\hline $12: 0$ & $2.3 \pm 0.33$ \\
\hline $14: 0$ & $2.87 \pm 0.31$ \\
\hline $16: 0$ & $40.59 \pm 5.44$ \\
\hline $18: 0$ & $4.32 \pm 0.99$ \\
\hline $18: 1$ & $22.29 \pm 0.32$ \\
\hline $18: 2$ & $14.46 \pm 1.41$ \\
\hline $18: 3$ & $13.20 \pm 0.51$ \\
\hline
\end{tabular}




\section{FIGURES}

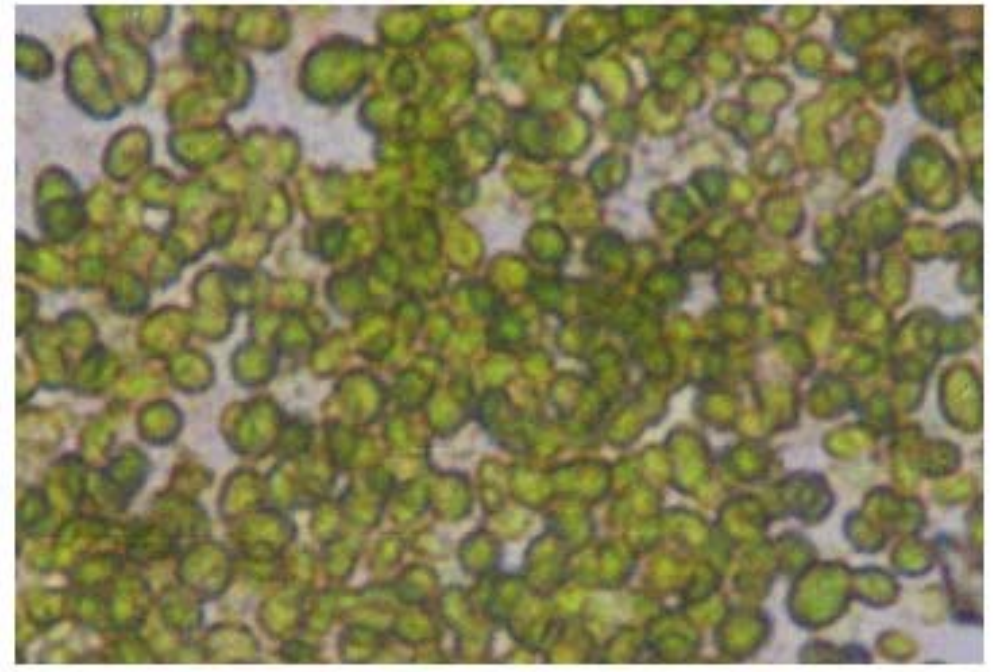

Figure 1. Light microscopic (40X) picture of the alga Botryococcus braunii (CFTRI-Bb1).

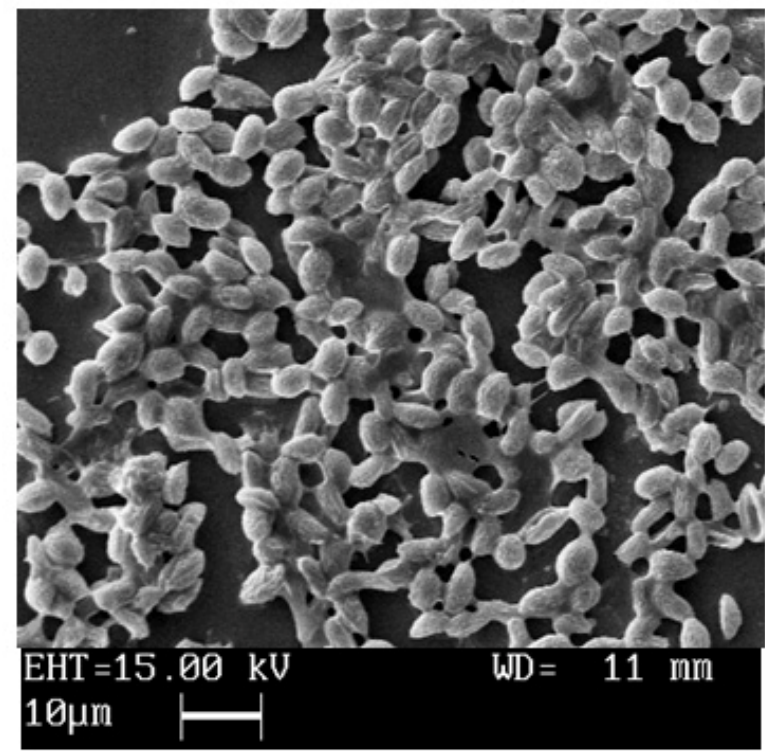

Figure 2. Scanning electron microscopic picture of the alga Botryococcus braunii (CFTRI-Bb1). 


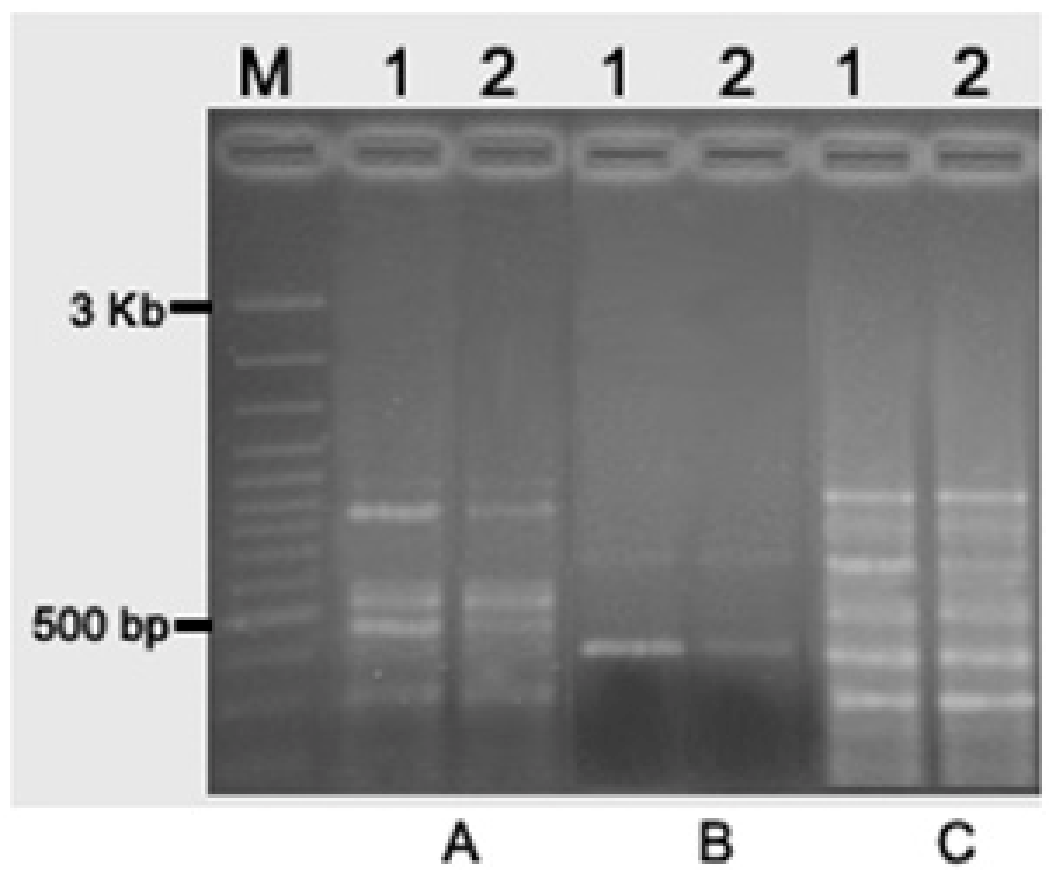

Figure 3. ISSR finger print of Botryococcus braunii (CFTRI-Bb1) and known strain of $B$. braunii (N-836). M: Marker; $A$ : (AC) ${ }_{8} C$; $B$ : $(\mathrm{GA})_{8} \mathrm{C}$; C: $(\mathrm{GA})_{8} \mathrm{~T}$; Lane 1: B. braunii (N-836); Lane 2: B. braunii (CFTRI-Bb1).

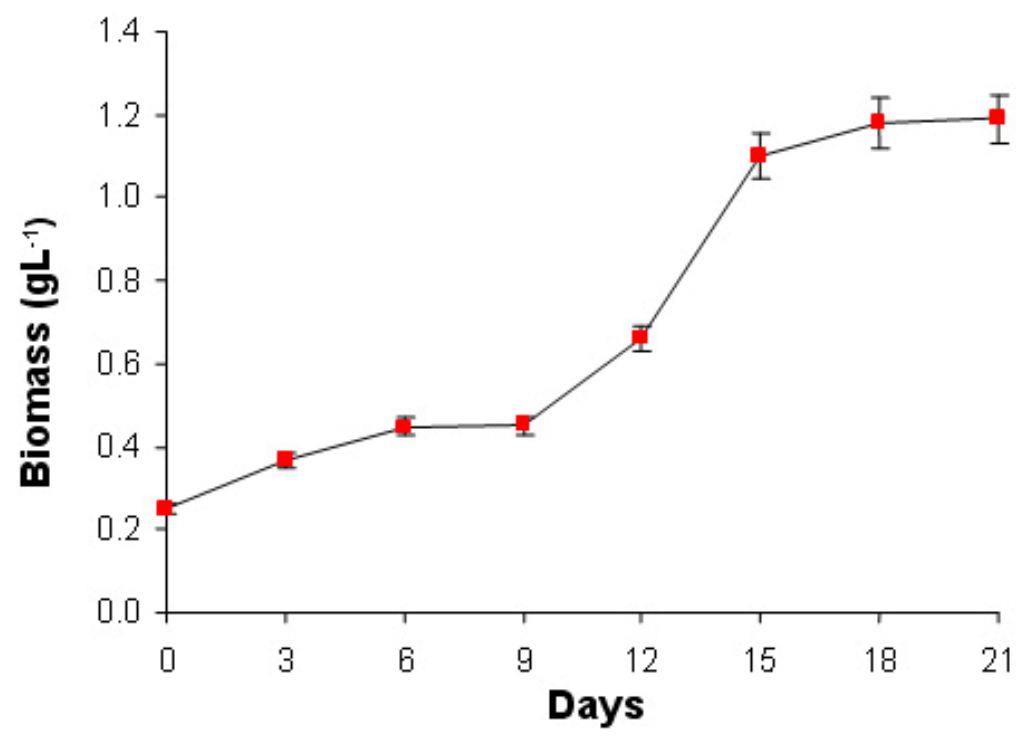

Figure 4. Growth curve of Botryococcus (CFTRI-Bb1). 


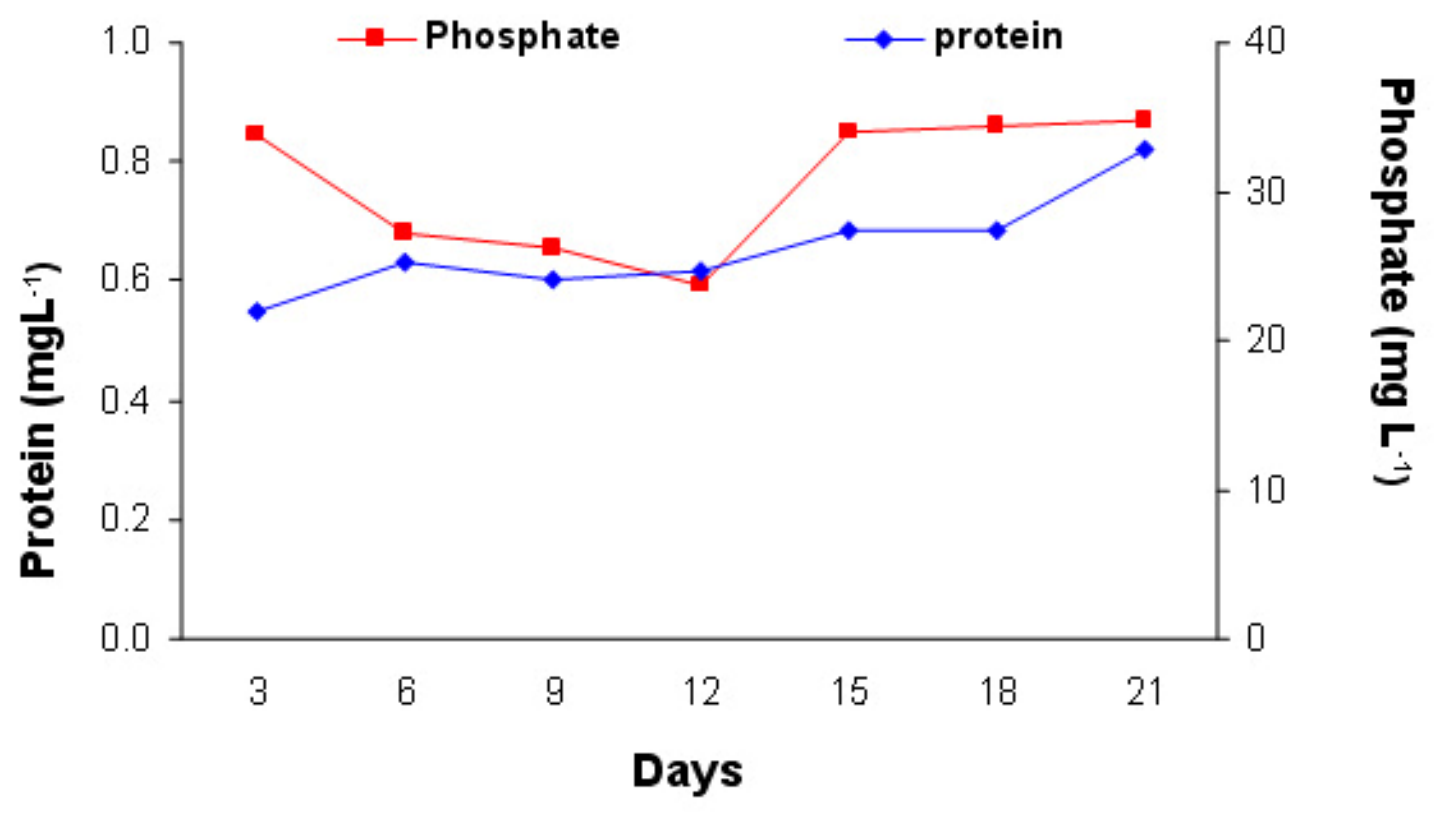

Figure 5. Concentrations of phosphate and protein in the Botryococcus braunii (CFTRI-Bb1) spent medium.

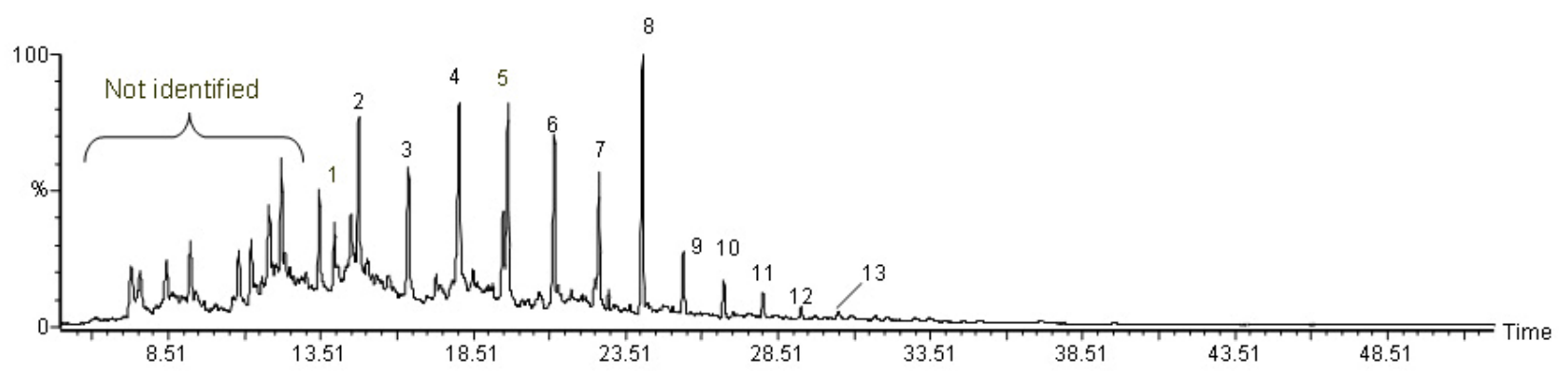

Figure 6. Gas chromatogram of hydrocarbons extracted from Botryococcus braunii (CFTRI-Bb1). Details of 1-13 peaks are given in Table 1. 
Peak 1

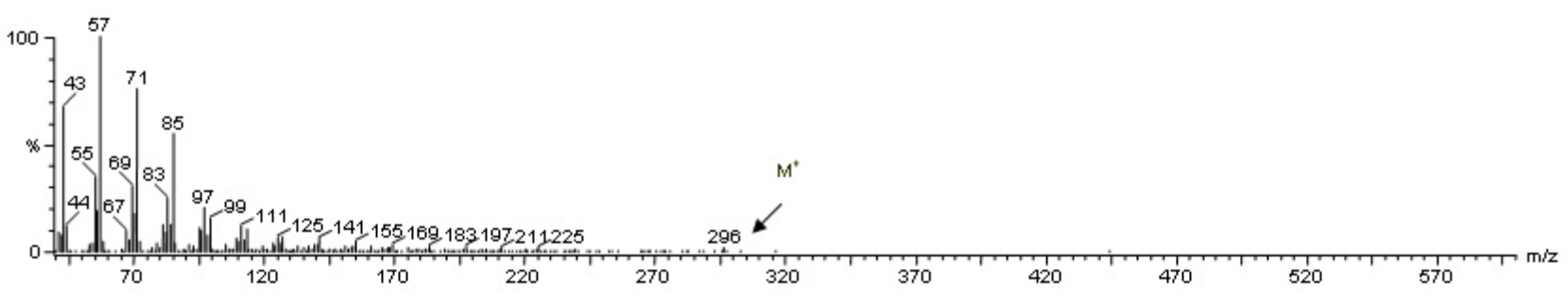

Peak 4

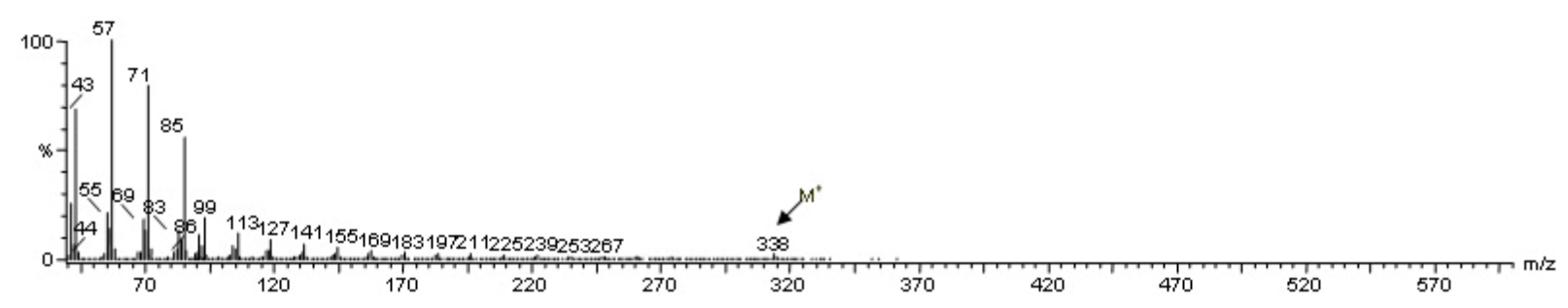

Peak 8

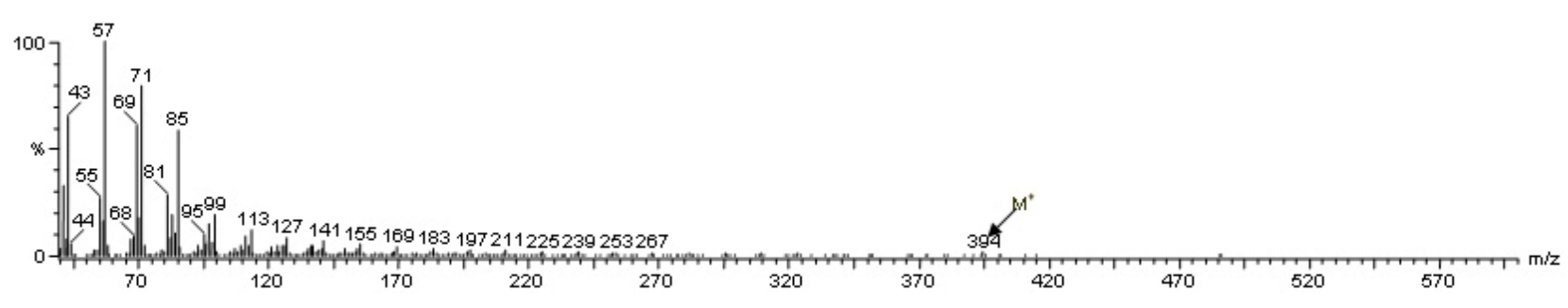

Peak 13

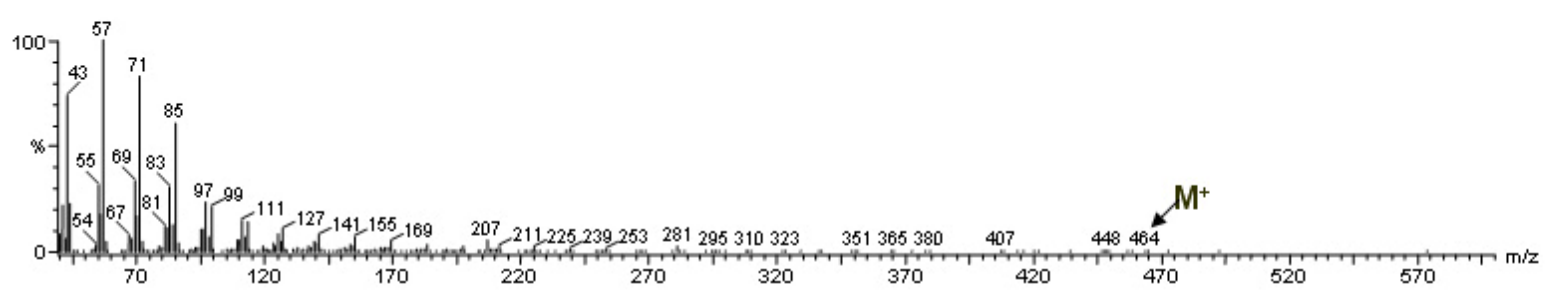

Figure 7. Mass spectra of saturated hydrocarbons produced by the alga Botryococcus braunii (CFTRI-Bb1). Peak 1: Heneicosane; Peak 4: Tetracosane; Peak 8: Octacosane; Peak 13: Tritriacontane. 


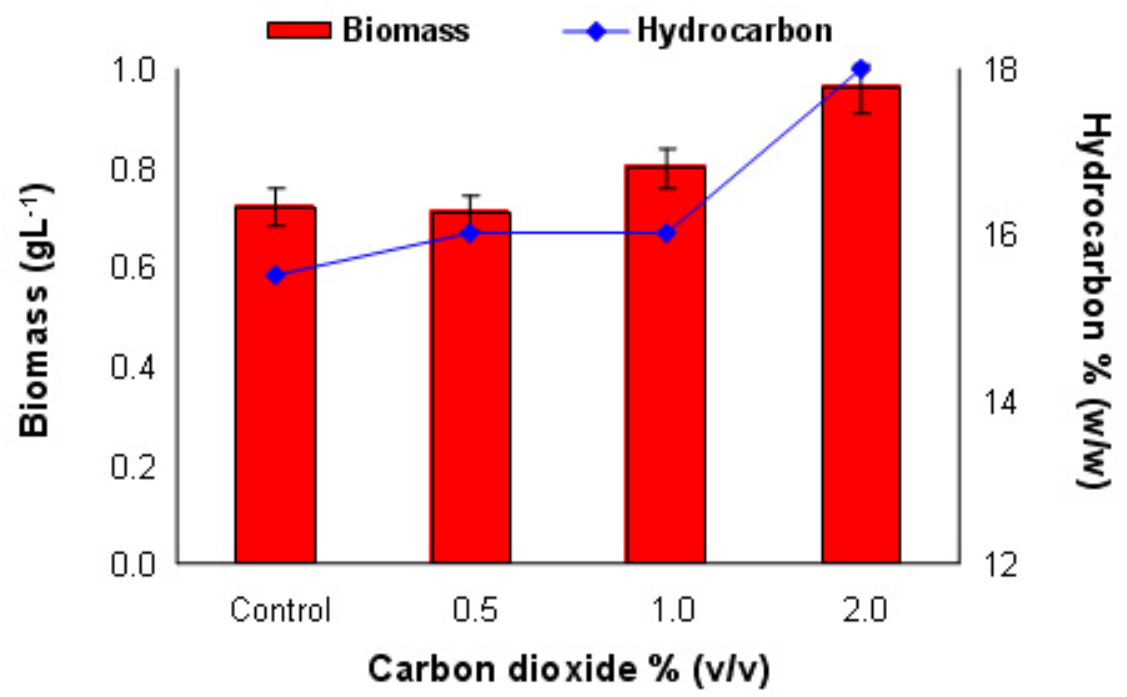

Figure 8. Effect of $\mathrm{CO}_{2}$ on biomass yields and Hydrocarbon production of Botryococcus braunii (CFTRI-Bb1).

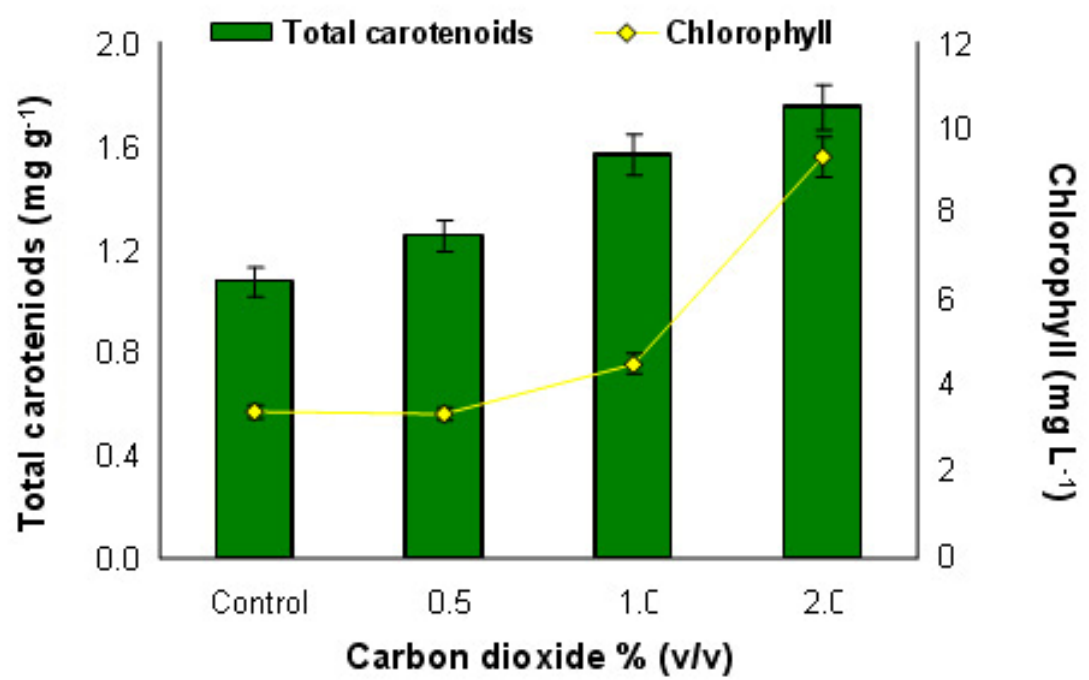

Figure 9. Effect of $\mathrm{CO}_{2}$ on carotenoids and chlorophyll contents of Botryococcus braunii (CFTRI-Bb1). 

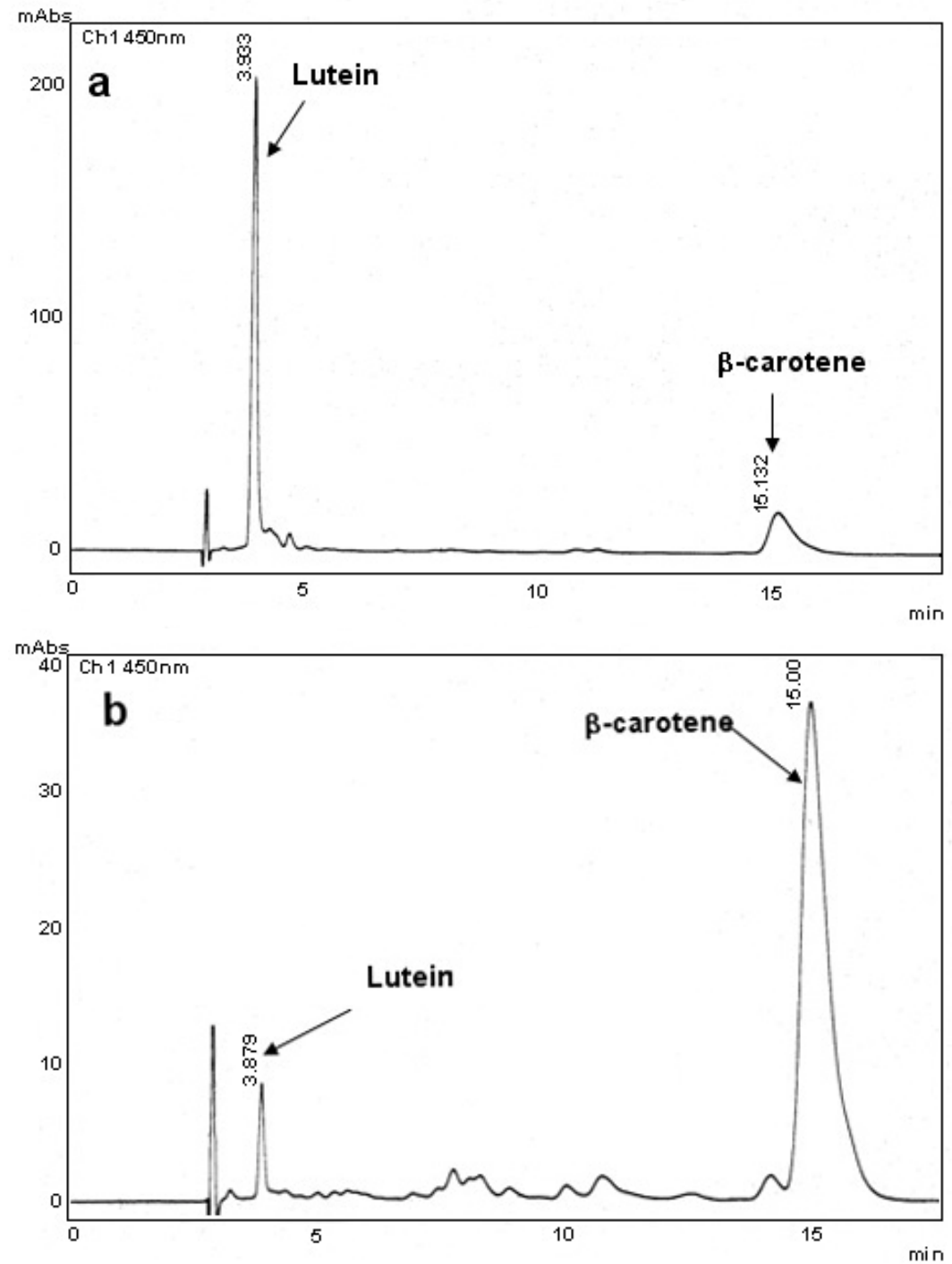

Figure 10. HPLC profiles of carotenoids of B.braunii (CFTRI-Bb1).

(a) Control culture.

(b) Culture supplemented with carbon dioxide. 
Dayananda, C. et al.

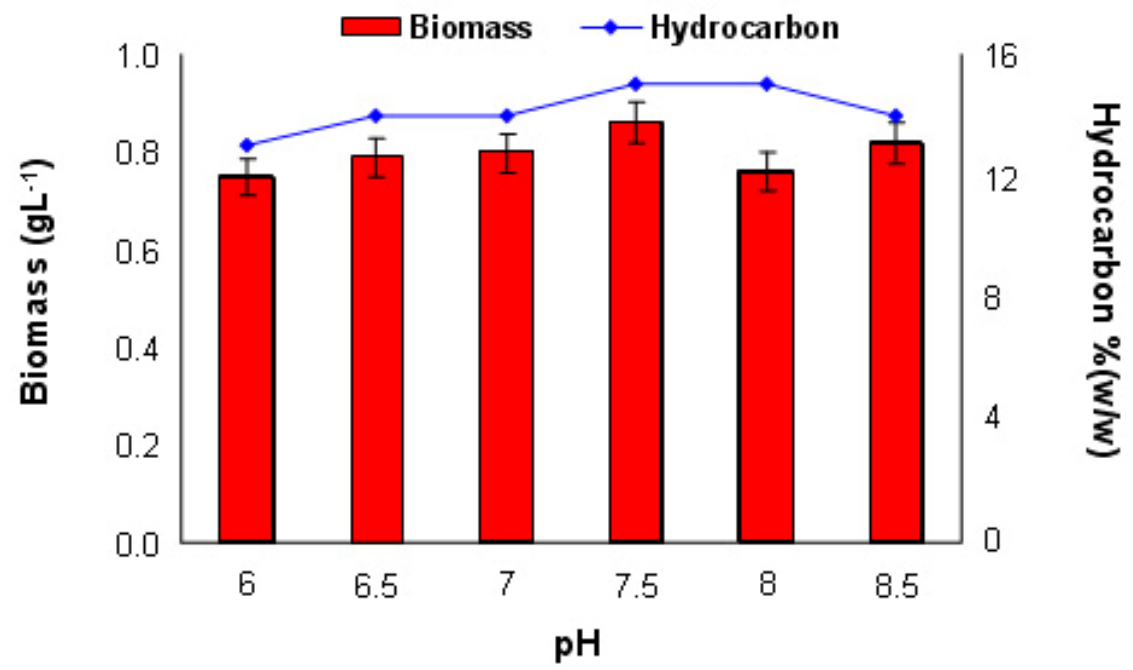

Figure 11. Effect of $\mathrm{pH}$ on the growth and hydrocarbon production in Botryococcus braunii (CFTRI-Bb1). 